\title{
Religion as a Core Value in Language Maintenance: Arabic Speakers in Greece
}

\author{
Nikos Gogonas*
}

\begin{abstract}
This paper presents the findings of research investigating language maintenance/shift among second-generation Arabic speakers in Athens using adolescents of mainly Egyptian origin and their parents as informants. Quantitative data on language competence and on patterns of language use within Egyptian households indicate language shift in adolescents of the Coptic religion. In contrast, Muslim informants emerge as language maintainers. Qualitative results originating from interviews with parents indicate that the significance of religious practice leads Muslims and Copts to view Arabic and Coptic respectively as core values for their identity. This distinction leads to a differentiation in patterns of Arabic language transmission between Muslim and Coptic Egyptian parents, reflecting both the different internal dynamics of these sub-communities, and their different relationships to the host society.
\end{abstract}

\section{INTRODUCTION}

Greece is a recent destination country for immigrants, after having exported emigrants mainly to Australia, the United States and Western Europe for many years. Although immigrants (mainly Egyptians and Pakistanis) began to arrive in Greece at the beginning of the 1970s, the first major wave of immigrants came in the 1990s (Antoniou, 2003). Most of these initially irregular migrants have settled in Greece and through repeated regularization programmes (in 1998, 2001, 2005 and 2007) have now become a largely legal immigrant population (Triandafyllidou and Gropas, 2009). Economic immigrants are estimated

* University of Athens, Athens, Greece. 
at 1.2 million, including co-ethnic returnees (Triandafyllidou and Maroufof, 2008). Main nationalities among the immigrant population include over half a million Albanian citizens, 150,000 co-ethnic returnees from the former Soviet Republics, between 110,000 and 120,000 Asians, and approximately 130,000 European Union citizens (mainly from Poland, Bulgaria and Romania) (Triandafyllidou and Gropas, 2009).

The linguistic profile of Greece was characterized by diversity even before the recent influx of migrants. However, ever since the first decades of the independent Greek state, the nation has been defined with reference to common ancestry (Kitromilides, 1983; Veremis, 1983, 1990), culture and language (Kitromilides, 1990). Greek national consciousness was 'constructed' throughout the 19th century with reference to the irredenta, namely the regions inhabited by Greek-speaking Christian Orthodox populations that had not been included in the Greek state at the moment of its creation. The Lausanne Treaty in 1923 contributed to the homogenization of the Greek population through the minority population exchange between Greece, on the one hand, and Turkey and Bulgaria on the other. Part of this homogenization process included the assimilation of ethnolinguistic and religious minorities that remained in Greece, such as speakers of Pomak (a variety related to Bulgarian, spoken by the Pomak Muslim minority of western Thrace), Romany (the language of the Rom related to dialects spoken in northern India), Ladino (a Romance language spoken by the Jewish community in Greece), Vlach (related to Romanian and spoken by communities in Thessaly and in the area of Pindos), Arvanitika (related to Albanian and spoken by communities in the area of Thebes and Athens, as well as in the Peloponnese and some of the islands) and Slavika (related to Macedonian and spoken by communities in the area of western Macedonia) (Sella-Mazi, 2001; Trudgill, 2002). From the aforementioned languages, Turkish is the only one that is officially recognized in Greece as a minority language, and is spoken by the Turkishspeaking minority of western Thrace (northeast Greece), a minority that is protected by the terms of the Treaty of Lausanne (1923).

Greece's resistance to acknowledge the existence of minorities within its territory can be seen as a result of the fact that most of them have been identified with territorial claims by neighbouring countries with which geo-political relations have always been tense (Rozakis, 1996). For example, because of Vlach's affinity with modern Romanian, in the early 20th century, the Romanian government established Romanian-medium schools in some areas of what is now Greece, aiming to instill Romanian 
national conscience among the Vlach population of Greece, with a view to annexing Romanian-speaking areas. Since the 1920s, however, there have been no such schools, except for one which survived more or less by accident in Ano Grammatiko (Greek Macedonia) until 1945 (Sella-Mazi, 2001; Winnifrith, 1992). The homogenization process of the Greek state towards the above-mentioned minorities has been generally successful. For example, both the Vlachs and the Arvanites demonstrate a very strong Greek national identity, and their feelings of connection with other nations, are, for the most part, nonexistent (Trudgill, 2002). This is further illustrated by the fact that the Arvanitika and Vlach languages are facing extinction (Sella-Mazi, 2001). The above background information may help explain why efforts to establish strategies and means for the maintenance of minority languages in Greece are in their infancy, especially insofar as these languages are related to 'traditional enemies' of the country (such as Albanians). Until now, the only concern that Greek political and educational institutions have voiced is the successful teaching of Greek as a second language, while issues raised by supporters of intercultural and anti-racist education, from both the academic and the educational contexts, have minimal and sporadic impact on the mainstream educational system, depending on the interest and enthusiasm of individual educators.

The present study explores issues in language maintenance and shift with reference to second generation Arabic speakers, a relatively small migrant community in Greece, through a humanistic sociology approach, the Core Value Theory.

\section{CORE VALUE THEORY}

A powerful explanatory model for studying language maintenance is the Core Value Theory developed by Smolicz through his studies of multilingualism in Australia. The term core value refers to:

Those values that are regarded as forming the most fundamental components or heartland of a group's culture, and act as identifying values which are symbolic of the group and its membership (Smolicz and Secombe, 1985: 11).

Abiding by or sharing specific core values is an indication of membership in a certain group, whereas rejecting these values is equivalent to potential exclusion from it (see Holeva, 2004). As described by Smolicz: 
Some items may be drastically alerted (...) without undermining the stability of the group. At the same time, there are other aspects of culture which are of such fundamental importance for its continued viability and integrity that they can be regarded as the pivots around which the whole social and identificational system of the group is organized. Removal of such pivots, through enforced "modernization" or assimilation to the dominant group, would result in the entire edifice crumbling to pieces (1992: 279).

Core values within minority groups are often associated with language because of the linkage between group identity and a native tongue (May, 2001, 2003; Tannenbaum, 2005). Many ethnic groups are strongly language-centred, so that their existence as distinct social and cultural entities often depends, in their own perception, on the maintenance and development of their heritage languages. Other groups may view other cultural elements (religion, family structure, or "visible" markers) as their core values, comparable to language in their significance (Smolicz and Radzik, 2004; Smolicz and Secombe, 1989; Smolicz, Secombe and Hudson, 2001). When language is perceived as a core value, language maintenance rates tend to reflect this (e.g., King, 2000; Smolicz, 1992; Smolicz and Secombe, 1985; Smolicz et al., 1990). Moreover, when language is closely intertwined with other core values, such as religion, the match between attitudes and actual maintenance is even higher, whereas when the language is isolated from other cultural aspects, the match is lower.

Central to the maintenance of Arabic, is the issue of "religious classical", that is, languages that are particularly related to the practice and continuance of religious ritual, and which are not the vernacular, everyday language of the community concerned. Fishman cites (Koranic) Arabic, Old Testament Hebrew, Ecclesiastical Greek and Latin as examples of "religious classicals". Moreover, as will be seen, the research presented in the current paper is instrumental in identifying Coptic as a member of this category of languages. According to Fishman, "No matter how highly regarded, how well-taught and how fluently learned, they remain additional languages for specific functions and do not become the mother tongue of subsequent generations" (Fishman, 1991: 360). Religious classical languages may however, become very important in maintaining boundaries between the host culture and the minority culture, a factor that Fishman regards as the basic issue in language maintenance. Their very existence does in fact presuppose a group or 
religious community that is separate from the mainstream religious institutions of the host country.

\section{EGYPTIANS IN GREECE}

\section{Demography}

From the early 1970s, Egyptians started to migrate into Greece, initially in relatively small numbers: 10,000 visas for potential Egyptian workers to Greece were issued in 1972 according to press reports (Iosifides, 1997). Estimations of the total African immigration population in Greece at the end of 1972 put the overall number at 20,000; these immigrants were Egyptians, Sudanese, Zambians, Ethiopians and Nigerians (Nikolinakos, 1973). It was in the early and mid-1980s that the influx of Egyptians started to swell, although the scale of the Egyptian presence in Greece is still very small in comparison with that of other nationalities. According to the 2001 census, the total population of Egyptians in Greece is only 7,846. At the same time, data by the Greek Interior Ministry on the regularization of Egyptian migrants in Greece indicate that in October 2007 the number of regularized Egyptians in Greece was a little over 10,000 people. $^{1}$ The percentage of legal Egyptians is presumably higher than that of other migrant groups because the majority have been residents in Greece for several decades. Egyptians are markedly clustered in one specific region the Athens metropolitan area. A secondary cluster of Egyptians are found in Evros, northeastern Greece (Rovolis and Tragaki, 2006). Egyptian migration seems to be maledominated. As the 2001 census indicates only 22 per cent of Egyptian immigrants in Greece are female.

\section{Employment and living conditions}

In a study comparing the living and working conditions among Albanian and Egyptian immigrants in Greece, 17 per cent of Egyptian migrants claimed they had been harassed or subjected to discrimination in Greece, while the percentage of Albanians who had faced discrimination was 48 per cent (Iosifides, 1997). Iosifides explains this difference by claiming that there have been traditionally good relationships between Greece and Egypt, due to long-standing trading patterns and more recent flows of tourists from Greece to Egypt and students from Egypt to Greece (1997). At this point it is worth mentioning that Greece, Egypt and the Arab world in general have traditionally good and 
Gogonas

trustful relationships (Iosifides, 1997). Before the "Egyptianization" of the economy by Nasser, a thriving Greek business and cultural community was based in Egypt (Issawi, 1963). In addition, during the occupation of Greece during the World War II, the Greek exile government, which guided the resistance movement in the occupied country, was based in Egypt. Relations with Arab countries and Egypt improved even further when the socialist government took power in Greece in 1981 (Iosifides, 1997).

There is little data available on the employment of Egyptians in Greece. A study by Al-Ani Muzahim Majid refers to Arabs in general, and it is assumed that Egyptians are also included. According to Majid in 1987 there were more than 200 Arab companies in Greece, which were employing a large number of Arabs (1991: 185). Examples were the Lebanese building company CCC, which employed 400 Arabs in its offices in Athens, and the Syrian shipping company Nautomar, employing around 100 Arabs. According to the same study, there are also Arab restaurants in Athens, which employ Arab personnel. Moreover, as there has been substantial student migration from the Arab countries, a large number of Arabs have entered prestigious professions such as medicine (Majid, 1991).

In the study by Iosifides, however, Egyptian men were found to work primarily as street-hawkers (1997). Clearly, the sample of Iosifides was not broadly representative of Egyptians in Athens, focusing only on those performing working-class or low-status jobs. Although there is no updated data on the housing patterns of Egyptians, in Iosifides's study, more than 50 per cent of them were satisfied with their accommodation (Iosifides, 1997). Similarly, Antoniou (2003) drawing on data from the 1998 regularization programme mentions that Muslim immigrants carry out low-paid jobs and are generally considered by the public as cheap and tax-free labour. The majority of immigrants living in the larger provincial cities, and especially Athens, are in most cases employed as unskilled manual workers. Immigrants usually reside in underdeveloped districts of the capital due to the existence of small and cheap houses or big apartments which are inhabited by large families or many unrelated individuals. Immigrants who cannot find alternative housing arrangements also live in old hotels located in the city centre.

\section{Institutional Support}

The following discussion refers to the religious rights of Arabic speakers in Greece. However, as information on the Coptic community is limited, 
more attention is paid to the religious rights of the Muslim community than to the Coptic religious group.

The Treaty of Lausanne frames the protection of the Muslim population's religious rights and is heavily influenced by the bilateral political relations between Greece and Turkey. Tense relations between the Greek and Turkish governments, as well as other national security matters, seem to affect the majority population's perceptions and concerns about the Muslim religion.

Thus, while the Orthodox Church of Greece is constitutionally recognized as the "legitimately dominant" religion in Greece, Islam enjoys a status as the religion of the autochthonous Muslim minority of Western Thrace. These distinctions in themselves have restricted religious freedoms in Greece and have led to a series of discriminatory legal and administrative practices that relate to the rights of religious groups (Triandafyllidou and Gropas, 2009).

This context may help account for the unfavourable stance of the Greek state to the establishment of authorized mosques in Athens. Especially after the exchange of the Muslim population of Greece with the respective Christian population of Turkey in 1923, the operation of mosques within the Greek state was limited to the region of Thrace, and the islands of Rhodes and Kos (Tsitselikis, 2004). Even though there are numerous mosques scattered throughout Greece, forming part of the country's Ottoman cultural heritage, none of them has been used for the needs of Muslim migrants that are permanently settled in metropolitan Athens (Tsitselikis, 2004). However, provisions for the construction of a mosque in Athens date from the 1880s (Triandafyllidou and Gropas, 2009). The issue was discussed again in 1913, while in 1934 special provisions were taken for the construction of an Egyptian mosque. However, this law also remained solely on paper while its main aim was to improve Greek-Egyptian relations with a view to protecting the Greek diaspora in Egypt (Triandafyllidou and Gropas, 2009). In 1984, some Sudanese university students asked the Greek authorities for a license in order to operate a mosque in Goudi, Athens. The Greek authorities refused the license but agreed to the operation of the mosque on the condition that "social peace" was assured in the area that the mosque would operate. Since then, prayer rooms have started to operate with the silent consent of the authorities, all without licenses and with the danger of being shut down at any time (Tsitselikis, 2004). Informal sources put the number of prayer rooms at over 100, mainly located in 
private apartments, basements, shops or storage facilities. In June 2007, an Arab Hellenic Center for Culture and Civilization was inaugurated in the Moschato neighbourhood in Athens, which although not an official place of worship is functioning as a formal one. With a capacity for 2,000 persons, three prayer halls and six imams, the centre was set up by private initiative (funded by a Saudi Arabian investor and run by an Egyptian) to serve as a community centre in which to hold meetings, social ceremonies, and Islamic prayer (Triandafyllidou and Gropas, 2009). As recently as 2006, a draft law on the subject of establishing a mosque was submitted to parliament by the ruling conservative party New Democracy. This bill proposed the establishment of a mosque in Eleonas, near the city centre of Athens area. It stipulated that the Greek Ministry of National Education and Religious Affairs would be exclusively responsible for constructing and financing it, and that it would be managed by an administrative board appointed by the same ministry. The mosque would be constructed on public premises and the ministry would be responsible for all related expenses. According to Triandafyllidou and Gropas, the establishment of a religious venue for the Muslim population in Athens is perhaps the most sensitive area in terms of popular perceptions and the way the state has attempted to respond to the religious needs of the growing immigrant population. However, researchers Triandafyllidou and Gropas, through an in-depth review of the debates (both in Greek parliament and in the press) that surrounded proposed law and, more generally, religious diversity in Greece, express concern about the law will finally be implemented and the Mosque built in Athens (2009: 12).

Similarly, no purpose-built Coptic church exists in Greece. The Coptic community have rented the floor of a building for their worship needs, although its bad condition makes it unfit for a church. Recently, the Greek government has finally approved the request by the Coptic community to establish a Coptic-Egyptian church.

There are two Egyptian associations in Athens. The aim of these associations is to inform Egyptian migrants about practical issues of working and living in Greece, such as how to obtain or renew residence and work permits. Moreover, they function as socializing places, although there is no available information about participation rates in these associations.

Greek law on intercultural education as well as a series of ministerial circulars include provisions allowing for mother-tongue teaching in 
migrant languages by bilingual teachers from the pupils' countries of origin. Despite these provisions, mother-tongue teaching has so far been implemented only in a limited number of schools in the country on an experimental basis, while the Ministry of Education does not approve of mother-tongue teaching.

There are two Arabic schools in Athens: the 7th of April Libyan school and Green Hill. The Libyan school was founded in 1979, is funded by the Libyan state and it follows the same curriculum as schools in Libya (Majid, 1991). Green Hill is a private international school with tuition in English and Arabic. Arabic is also taught at the Egyptian Embassy and in the Hellenic-Arabic Cultural Center in Athens. Apart from the Arabic language however, Christian (Coptic) Egyptian children are taught the Coptic language in the premises of their Coptic church in Athens.

With regard to Arabic language media in Greece, we note the following: the Athens Weekly Report is an Arabic language newspaper published in Athens, and in addition there are ten imported daily newspapers in the Arabic language (Georgiou, 2002). There is also a broadcast in the Arabic language on the Greek radio while Arabic channels can be watched through satellite TV.

\section{THE PRESENT STUDY}

The main aim of this study is to assess whether there is language shift among Egyptians in Greece, according to the Core Value Theory. The study addresses the following research questions: (1) How extensive is language shift in the children of Egyptian immigrants? (2) What are some of the factors that affect this shift?

\section{INFORMANTS}

Data collection lasted from January to December 2005. For sample uniformity I only included pupils who attended Greek state schools. Finding an adequate number of Egyptian pupils for statistical analysis proved to be problematic, as the number of Egyptian pupils in Greek schools is very small. In fact, according to statistics by Baldwin-Edwards et al. (2004), during the 2002-03 school year there were only 216 Egyptian pupils enrolled in Greek state schools. For this reason, I had to 
extend the sample to Arabic speakers from other Arab countries. I finally found 32 Arabic-speaking pupils in total, of whom 25 came from Egypt and seven from Syria, Lebanon, the United Arab Emirates, Iraq, Jordan and Sudan. Of these 32 children, 22 were contacted from religious establishments (the Coptic church and the Hellenic-Arabic Center), and the remaining ten were from a Greek state intercultural school.

Of the 32 pupils, 18 were girls and 14 were boys and their mean age was 13.7 years. Of them, 15 were born in Greece, while the rest migrated to Greece from 1993 to 2004. In this paper we define the second generation as children born in the host country of one or more immigrant parents or those who arrived before primary-school age Portes and Zhou (1993), Thomson and Crul (2007). Twenty pupils were of Christian Coptic religion while the remaining 12 were Muslim.

There were 14 interviews with parents, nine with mothers and five with fathers. Of this group, 11 came from Egypt, two came from Syria and one came from Lebanon. The mean age of the parents was 42.7 years and at the time of the interview they had been in Greece an average of 17 years. Seven parents were Muslim and seven were Coptic. Last, there were ten interviews with pupils.

\section{INSTRUMENTS}

The pupils' questionnaire consists of sociolinguistic information on: the self-evaluation of language skills in the ethnic language and in Greek, and language use in the home and at school. Egyptian pupils were asked to evaluate their language competence in Greek and the parental language on a four-point scale, ranging from "not at all" to "very well", in four language skills, namely, speaking, understanding, writing and reading. They also had to designate the language they use most with various interlocutors, such as parents, older relatives, siblings and co-national friends.

The aim of the interviews with Egyptian parents was to examine their attitudes toward Arabic language maintenance, and their involvement in transmitting the mother-tongue to their children through the use of Arabic with their children at home, through teaching them the ethnic language, or encouraging them to attend mother-tongue classes. Moreover, interviews with Arabic language teachers as well as with the director of the Hellenic-Arabic (Muslim) Center provided very enlightening data on 
issues of parental attitudes to language maintenance and transmission. Interviews with Coptic parents were conducted in Greek. In the case of Muslim parents, sometimes English was used, and at other times one of the teachers at the Hellenic-Arabic Center acted as an interpreter. (This fact is indicative of the difference in Greek language skills between the two sub-communities). Each interview lasted for approximately 45 minutes.

The software package, Statistical Package for Social Sciences (SPSS) was used to analyse the quantitative data. This was able to extract simple frequencies, such as showing how many pupils belonged to each age group; do cross-tabulations, such as finding out the gender composition of each age group; and use the inputted data to create new categories, such as pupils who had read a book in Arabic in the last week.

\section{LIMITATIONS}

Certain factors have to be taken into account in the analysis of the pupils' survey. The fact that the study was carried out in the Greek language and by a Greek national may have had a bearing on their responses both with reference to self-assessments of linguistic skills and language use. Another reason why results on language competence and use have to be treated with some caution is the high element of subjectivity attached to self-assessment (McKinnie and Priestly, 2004). Indeed, although Lemmon and Goggin found that self-ratings adequately reflected language abilities, they conclude that "subjects may not accurately assess their language skills, and may rely too heavily on inappropriate comparison groups or show a social desirability bias" (1989: 142). Delgado et al. (1999) found that the validity of self-assessments varied on different tasks, that they may be susceptible to a social desirability bias, and that the stimulus language may affect responses.

The fact that I am a Greek national - a member of the host country implied that I would have to take measures in order to ensure a certain degree of trust with immigrant participants, as interviewees might not have felt comfortable in expressing their true feelings to a member of the host society in an interview taking place in the host country. This is the reason why the intermediation of members of the Egyptian community who acted as "referees" for me as the researcher, was necessary in contacting informants. Another issue has to do with the fact that Coptic-Egyptians may have given me socially desirable answers: as will 
be seen, Coptic Egyptian adults, being aware of the significant role that the Christian Orthodox religion plays for the Greek population may be manipulating a "common Christian identity" with Greek people and express inimical attitudes to Muslim Egyptians. It remains to be seen whether they would have the same attitude had the researcher been of non-Greek origin.

Another limitation clearly relates to sample size, especially regarding the quantitative part of the study. Obviously, no robust generalizations on language maintenance can be made, based on data from 20 Coptic Arab and 12 Muslim pupils. On the other hand, interviews with the parents seem to constitute valuable evidence in this study with regard to factors affecting language maintenance and shift within Arabic-speaking communities.

\section{RESULTS}

The results presented below refer to: a) Egyptian pupils' self-assessments of language competence in Arabic and Greek and language choices with various interlocutors. The data indicate language shift into Greek for Coptic Egyptians and language maintenance for Muslim pupils; b) factors affecting language maintenance/shift in Egyptian households, namely parents' attitudes toward mother-tongue maintenance, language transmission in the home, parental initiatives for mother-tongue teaching and parents' attitudes toward the host population.

\section{DATA INDICATING LANGUAGE MAINTENANCE/SHIFT}

\section{Egyptian children's linguistic proficiency in Greek and in the mother tongue.}

This section examines the linguistic proficiency of Egyptian pupils in the parental language and in Greek from quantitative data reported by the informants themselves.

The results in Table 1 indicate considerable differences in the language skills reported for the two languages by Coptic and Muslim Egyptian pupils. In the case of Coptics, we notice an overall dominance of Greek over Arabic in the pupils' assessment of their linguistic repertoire. 
TABLE 1

EGYPTIAN PUPILS' SELF-ASSESSMENTS OF GREEK AND ARABIC LANGUAGE SKILLS

\begin{tabular}{|c|c|c|c|c|}
\hline \multirow{2}{*}{$\begin{array}{l}\text { Skills } \\
\text { Understanding }\end{array}$} & \multicolumn{2}{|c|}{ Coptic Pupils } & \multicolumn{2}{|c|}{ Muslim Pupils } \\
\hline & Greek & Arabic & Greek & Arabic \\
\hline Very well & 8 & 9 & 9 & 11 \\
\hline Fairly well & 1 & 7 & 3 & 1 \\
\hline Not very well & 1 & 4 & - & - \\
\hline Not at all & - & - & - & - \\
\hline Speaking & Greek & Arabic & Greek & Arabic \\
\hline Very well & 18 & 8 & 8 & 11 \\
\hline Fairly well & 1 & 7 & 4 & 1 \\
\hline Not very well & 1 & 3 & - & - \\
\hline Not at all & - & 2 & - & - \\
\hline Reading & Greek & Arabic & Greek & Arabic \\
\hline Very well & 17 & 3 & 7 & 11 \\
\hline Fairly well & 2 & 3 & 4 & 1 \\
\hline Not very well & 1 & 6 & 1 & - \\
\hline Not at all & - & 8 & - & - \\
\hline Writing & Greek & Arabic & Greek & Arabic \\
\hline Very well & 16 & 2 & 6 & 8 \\
\hline Fairly well & 3 & 2 & 3 & 4 \\
\hline Not very well & 1 & 7 & 3 & - \\
\hline Not at all & - & 9 & - & - \\
\hline
\end{tabular}

(Coptic pupils $\mathbf{N}=\mathbf{2 0}$, Muslim pupils $\mathbf{N}=12$ ).

In contrast, Muslim Egyptians report higher competence in all four skills in Arabic over Greek,

\section{Egyptian children's language choices}

Research in various contexts indicates that the age or generation of the interlocutor determines the language used by the children (Extra and Yagmur, 2004; Li Wei, 1994; Stubbs, 1985). Whatever language children use with their parents, they employ the majority language in communication with their siblings and peers, especially in the absence of parents (Clyne, 1990; Smolicz and Harris, 1976).

In accordance with the aforementioned research, results of the present study indicate that both Muslim and Coptic-Egyptian pupils use mostly the ethnic language with adults such as a mother, father, older relatives. 
Again, we note that the percentage of Muslim Egyptians who use more Arabic with adults is higher than the Coptic Egyptians. When it comes to language choices with young speakers, the majority (70\%) of Coptic Egyptians make use of Greek with siblings and others their age. On the other hand, the percentage of Muslim Egyptians who use Greek with siblings and others their age is much lower (17\%). Half of them report speaking both Greek and Arabic, while a considerable percentage $(33 \%)$ make use of Arabic.

In sum, results on Egyptian children's language skills and language choices have demonstrated that Coptic-Egyptian pupils are undergoing language shift, while Muslim Egyptian pupils show significant signs of Arabic language maintenance.

\section{FACTORS AFFECTING LANGUAGE MAINTENANCE/SHIFT}

\section{Parents' attitudes to mother-tongue maintenance}

Qualitative data reveal certain differences with regards to both the attitudes toward and the degree of language transmission between Coptic and Muslim Egyptian parents. When asked for reasons why they would like their children to maintain Arabic, Coptic Egyptians mention "the educational value of multilingualism" and "communication with members of the community", as the most important reason, which the following two excerpts exemplify:

Not because it is our mother-tongue, but because it is a pity not to learn better an extra language, especially if we take into account how many years he (my son) has been attending English private school in Greece - since he was six (Egyptian father, Copt religion, 38, Athens).

If they happen to visit relatives in Egypt they should know the language (Egyptian mother, Copt religion, 43, Athens).

Muslim Egyptians follow a different rationale in their classification, with "religious identity" as the most important reason.

I would like them to know good Arabic because even though they were born and live here I wouldn't like them to be cut off from their roots, language and religion (Egyptian mother, Muslim religion, 30, Athens). 
The Koran is only in Arabic you know. Therefore it is imperative for the children to know Arabic. We want our children to know their language, religion and history (Egyptian mother, Muslim religion, 42, Athens).

\section{Intergenerational language transmission in the home}

Data from Tables 2 and 3 indicate that Muslim parents make more use of Arabic with their children than Coptic parents, an additional factor enhancing language maintenance within the Muslim subgroup. Moreover, among Muslim speakers, language compartmentalization is at work, with children being exposed to Arabic at home and Greek at school. The following interview excerpts from a Syrian mother of Muslim religion and with the director of the Hellenic-Arabic Center illustrate this practice:

TABLE 2

EGYPTIAN (COPTIC) PUPILS' LANGUAGE CHOICES WITH VARIOUS

INTERLOCUTORS $(\mathrm{N}=20)$

\begin{tabular}{|l|ccccc|}
\hline & $\begin{array}{c}\text { Child and } \\
\text { Mother }\end{array}$ & $\begin{array}{c}\text { Child and } \\
\text { Father }\end{array}$ & $\begin{array}{c}\text { Child and Adult } \\
\text { Relatives }\end{array}$ & $\begin{array}{c}\text { Child and } \\
\text { Siblings }\end{array}$ & $\begin{array}{c}\text { Child and } \\
\text { Egyptian } \\
\text { Friends }\end{array}$ \\
\hline $\begin{array}{l}\text { Mostly/only Greek } \\
\text { Equally Greek and }\end{array}$ & 4 & 5 & 5 & 14 & 11 \\
$\begin{array}{c}\text { Arabic } \\
\text { Mostly/only Arabic }\end{array}$ & 9 & 9 & 6 & 4 & 6 \\
\hline
\end{tabular}

TABLE 3

EGYPTIAN (MUSLIM) PUPILS' LANGUAGE CHOICES WITH VARIOUS INTERLOCUTORS $(\mathrm{N}=12)$

\begin{tabular}{|l|ccccc|}
\hline & $\begin{array}{c}\text { Child and } \\
\text { Mother }\end{array}$ & $\begin{array}{c}\text { Child and } \\
\text { Father }\end{array}$ & $\begin{array}{c}\text { Child and Adult } \\
\text { Relatives }\end{array}$ & $\begin{array}{c}\text { Child and } \\
\text { Siblings }\end{array}$ & $\begin{array}{c}\text { Child and } \\
\text { Egyptian } \\
\text { Friends }\end{array}$ \\
\hline $\begin{array}{l}\text { Mostly/only Greek } \\
\text { Equally Greek and }\end{array}$ & 1 & 1 & 2 & 2 & 2 \\
$\begin{array}{l}\text { Arabic } \\
\text { Mostly/only Arabic }\end{array}$ & 7 & 3 & 3 & 6 & 6 \\
\hline
\end{tabular}


The kids are exposed for more hours per day to Arabic than to Greek. Our visitors speak Arabic, the grandparents speak Arabic, we speak Arabic, the TV is in Arabic. They are only exposed to Greek at school (Syrian mother, Muslim religion, 45, Athens).

Ninety per cent of the children speak Arabic with their parents at home. One reason for this is that parents don't speak good Greek. Even if the child speaks in Greek with siblings, with parents s/he will always speak in Arabic (Director, Hellenic-Arabic Cultural Centre, Athens).

\section{Parental initiatives for mother-tongue teaching}

As far as language teaching is concerned, the majority of Muslim parents send their children to attend mother-tongue classes at an unofficial mosque called the "Hellenic-Arabic Cultural Center", founded in 2001. It offers Arabic and Greek classes to Arab children. The teachers get paid a very small fee by contributions of the parents. Attendance at the centre lasts for six years, starting from nursery school. The courses taught are language, history, religious education and reading of the Koran (in classical Arabic). Children are taught Arabic three hours every week. These three hours include 1.5 hours of teaching and 1.5 hours of various activities in colloquial Arabic. Parents are very interested in maintaining the language and therefore they keep asking the centre to increase the number of teaching hours per week. Most of the teachers at the centre are ex-school teachers from Arab-speaking countries. Others are university graduates in various disciplines. The teaching materials used are the same as the ones used in schools in Egypt, and they are not suitable for Arab children who grow up in another country. The majority of the pupils sit language exams at the Egyptian Embassy. If they pass these exams, they can get certification with which they can attend Egyptian school if they return to Egypt. The majority of the Muslim parents interviewed express their satisfaction with the Hellenic-Arabic Center:

I am very happy with the Muslim centre [i.e. the Hellenic-Arabic Center]. Religion is very important for our community. Our children get to know other Arab children here, and this is very important. We come every Saturday. My son comes every Friday too with his father to pray. During Ramadan, he sleeps at the Center and he reads the Koran. The boy enjoys all [of] this (Egyptian mother, Muslim religion, 37 , Athens). 
Moreover, as was mentioned above, there is a fully-fledged Arabic school in Athens, called the Libyan School. According to the head teacher of the Hellenic-Arabic Center:

The children who attend the Arabic (Libyan school) are children who are almost sure they will return home and therefore their parents feel that attending Arabic courses such as the ones offered by the Centre once a week would not be enough.

Interviews with Coptic Egyptian parents indicate that Coptic Egyptian children do not attend the Libyan school. In the following quote, a Coptic Egyptian father who was a very active member of the Coptic community explains that this was due to religious reasons:

Ninety-nine per-cent of Christian Egyptians send their children to Greek schools or to private European schools. No Christian parents send their children to the Libyan school, apart from some very recent arrivals to Greece, perhaps who send their children there as they don't speak any Greek. Even if I were to return to Egypt my son would attend Greek school. We also like the religious education that is taught in Greek school, because it is very important for us as our religion is exactly the same [as Greek-Orthodox religion] (Egyptian father, Coptic religion, 39, Athens).

The following interview excerpt indicates that Coptic Egyptians place a higher emphasis on the teaching of the Coptic language over the teaching of Arabic:

Coptic is the ancient language that we use in the church. It is like Greek but it has seven more letters. Some people speak it at home but it is extremely rare. Coptic language classes take place every Saturday afternoon in our church but as my son doesn't have time to go there, because it's a little far, he is taught by a teacher in our neighbourhood, with a group of other kids (Egyptian mother, Coptic religion, 43, Athens).

\section{Parents' perceptions of and relations to the host population}

Qualitative data reveal a significant difference in terms of how each subcommunity perceives it's positioning in Greek society and its relations to the indigenous population. Thus, Coptic Egyptians, on the whole, demonstrate more positive attitudes towards Greeks. One of the reasons for the positive attitudes of the Coptic Egyptian group to the majority 
population seems to be the Coptic religion and its perceived similarities with Orthodox Christianity. In support of this claim, interview and observational data indicate that Coptic Egyptians prefer to socialise with Greek people rather than with Muslim Egyptians. In many cases they even express "inimical" views against the latter, as the following quotes illustrate:

We don't have any contacts with Muslims because we don't have time and because most of our free time we spend at the Coptic church or with people from the church. In the past the relations between us were better. Christians in Egypt have problems however. They are discriminated against. Egypt used to be our country, a Christian country. Islam came in [the year] 14-something. This is why there are 22 million Christians there out of 70 million Egyptians. Greeks like us more because we are Christian. But we feel the same. This was the primary reason why we came to Greece. In our Church, two thirds of the masses take place in Greek. Also some psalms are in Greek. Here you can live as you might in Egypt. Also there were a lot of Greeks in Egypt [Alexandria] and my father had very good relations with them. With other Arabs we just say 'hello' here, we don't have friendships (Egyptian father, Coptic religion, 40, Athens).

Muslim Egyptians are fanatic and we don't like them very much. We used to live like foreigners in our own country in Egypt because we were Christians. They are people who are closed to themselves [the Muslims]. I never had any communication with them in Greece. We have only Greek friends. In Egypt you have to have Muslim friends because they are the majority. Christians don't find good jobs in the Egyptian state. This is why we take our children to Greece. My children never felt [like] foreigners in Greek school, but they would feel foreign in Egypt. In Egypt they must also learn the Koran at school and I wouldn't like them to go to school there. We don't like their fanaticism (Egyptian father, Coptic religion, 45, Athens).

Attitudes such as the ones expressed above by Coptic Egyptians to Muslim Egyptians, stereotypical as they may seem, were recurrent in almost all my interviews with Coptic Egyptians. On the other hand, Muslim parents express their concern about the 'inimical' attitudes of Greek society on the grounds of their religion. To this, they add their indignation about the non-existence of a mosque in Athens. ${ }^{2}$ The following interview excerpts are indicative:

We don't have rights in Greece. They don't respect our religion in Greece. When my husband's boss found out that it was Ramadan, and 
my husband was tired because he was not eating, he gave him harder work to do especially then. We have a lot of your churches in our country. Here, you don't have a mosque. Why? There should be at least one in Athens (Egyptian mother, Muslim religion, 47, Athens).

Men come to this place here to pray. In small houses like that. Sometimes we feel insecure because we can't collect the money to pay the rent. The state is aware of the existence of these impromptu mosques but does nothing to build a proper mosque for us. The way things are now, we have to keep our religion secret. We rent small houses and there are curtains all around so that people won't see us from outside. It's as if we are doing something bad. If there were a proper mosque Greek people would also learn about Islam. Because they don't know anything about Islam, only that it means Turkey, that they have tortured people, and stuff like that (Egyptian mother, Muslim religion, 44, Athens).

The headscarf reminds Greeks of the Turks. Once in the metro there was an empty seat next to me and an old man was standing up. When someone showed him the vacant seat next to me he shouted: 'What are you talking about? Me sit next to a Turkish woman?' Young Greeks also get subjective information about Islam from Greek media and books. They don't learn the objective truth about us. Our voice cannot reach them and as a result the distance between us grows (Egyptian mother, Muslim religion, 43, Athens).

The above discussion indicates a positive orientation on the part of the Coptic group towards the indigenous population while the Muslim group seems to have internalised the scepticism and unfavourable attitudes regarding Islam in Greek society.

\section{CONCLUDING DISCUSSION}

As already discussed, the admittedly small sample of this study does not allow generalizations concerning the language maintenance/shift phenomenon within second-generation Arabic speakers in Greece. Therefore, the following conclusions that emerge from the comparison of the two distinct religious communities regarding Arabic language maintenance in Athens should only be taken as tentative.

The quantitative part of the study indicates that Egyptian pupils of Coptic religion are undergoing language shift. Young speakers demonstrate a preference for the use of Greek in interactions among themselves, 
while using Greek less frequently with adults. In contrast, Muslim Egyptian pupils are dominant bilinguals in Arabic, they are more literate in Arabic than Coptic Egyptians, and make systematic use of this language in most domains. Qualitative data reinforce these findings, as is indicated by the active involvement of Muslim parents with Arabic language maintenance and transmission to the second generation.

It seems that religion rather than language emerges as a core value for the Arabic speakers in this study. Although there is not an official mosque in Athens, the Muslim community has created its own places of worship which at the same time function as places of socialization and run mother-tongue classes. The Coptic Egyptians have organized a Coptic church, where the Coptic language is taught, as this is the language of religion for them. Moreover, Coptic-Egyptian parents demonstrate both a better knowledge of Greek and a higher motivation to integrate into Greek society than do Muslim Egyptians. Muslim Egyptians resist the intrusion of Greek in the home domain more than the Coptic Egyptians. This is related to the Muslim Egyptians' religious and cultural distance from the mainstream (Fishman et al., 1985). Unlike the Muslim Egyptians in Greece who perceive the cultural and linguistic boundaries between their group and the majority group as hard, Coptic Egyptians perceive cultural proximity between their group and the local population; these are factors that favour language maintenance among Muslim Egyptians while promoting language shift in Coptic Egyptians.

A perspective for considering these findings is the diglossic separation between literary and spoken variations of Arabic; Literary Arabic (which includes Classical and Modern Standard Arabic) is the standard language of literature, the media, and, most crucially, the Koran. Arabic speakers are first introduced to it at school. Locally oriented spoken vernaculars in the Arab world are open to variations and are constantly changing under the pressures of vernacular usages. These vernaculars are the language used for daily communication within the family, between friends, and in informal interaction, leading to a clear functional separation between "high" and "low" varieties (Badawi, 1985; Ferguson, 1959). Possibly only one variety serves as a core value in terms of identity or of links between language and identity. Thus, some of the Muslim adults interviewed seem to explicitly link issues of identity with literary Arabic, apparently viewing it as a connection to the entire Arab nation, the Islamic world, the classics, and so forth - a finding confirming the emphasis that Spolsky (2004) places on the strict association between classical Arabic and Islam, including the reading of the 
Koran and prayer. By contrast, Coptic speakers, when referring to Arabic language maintenance emphasize day-to-day communication, or the family context, all of which represent the spoken dialect. The reason is that the language that fulfils the role of core value for them is Coptic, their classical liturgical language. The specific significance of each variety to members of this minority group is a question requiring further research.

\section{NOTES}

1. http://www.antigone.gr/statistics/.

2. see discussion on pages $8-10$.

\section{REFERENCES}

Antigone (Information and Documentation Centre on Racism, Ecology, Peace and non-violence)

2007 "Statistics by the Greek Ministry of Interior on the number of foreigners residence permits by nationality", 15 October 2007, http://www.antigone.gr/statistics/.

Antoniou, D.

2003 "Muslim immigrants in Greece: religious organization and local responses", Immigrants and Minorities, 22: 2\&3: 155-174.

Antonopoulou, N., A. Tsangalides, and M. Moumtzi

2000 The Teaching of Greek as a Foreign/Second Language. PrinciplesProblems-Perspectives, Centre for the Greek Language, Thessaloniki (in Greek).

Badawi, E.M.

1985 "Educated spoken Arabic: a problem in teaching Arabic as a foreign language", in K. R. Jankowsky (Ed.), Scientific and Humanistic Dimensions of Language, Georgetown University Press, Washington, DC: 15-22.

Baldwin-Edwards, M.

2004 Statistical Data on Immigrants in Greece: An Analytic Study of Available Data and Recommendations for Conformity with European Union Standards, Mediterranean Migration Observatory, UEHR, Panteion University, Athens.

Clyne, M.

1990 Community Languages. The Australian Experience, Cambridge University Press, Cambridge.

Clyne, M., and S. Kipp

1999 Pluricentric Languages in an Immigrant Context, Mouton de Gruyter, Berlin. 
Delgado, P.

1999 "Self-assessment of linguistic skills by bilingual Hispanics", Hispanic Journal of Behavioral Sciences, 21(1): 31-37.

Extra, G., and K. Yagmur (Eds.)

2004 Urban Multilingualism in Europe. Immigrant Minority Languages at Home and School, Multilingual Matters, Clevedon.

Ferguson, C.A.

1959 "Diglossia", Word, 15: 325-40.

Fishman, J.A.

1991 Reversing Language Shift, Multilingual Matters, Clevedon.

1985 The Rise and Fall of the Ethnic Revival: Perspectives on Language and Ethnicity, Mouton Publishers, New York.

Georgiou, M.

2002 Mapping Minorities and Their Media: The National Context Greece, London School of Economics, London, http://www.lse. ac.uk/collections/EMTEL/Minorities/papers/greekreport.pdf.

Hellenic Migration Policy Institute

n.d. "Imepo", http://www.imepo.gr.

Holeva, A.

2004 "Current trends of the linguistic and cultural values of the Greek Australian community in South Australia", International Education Journal, 4(4): 212-25.

Iosifides, $\mathrm{T}$.

$$
\text { tion Journal, 4(4): 212-25. }
$$

1997 Recent Foreign Immigration and the Labour Market in Athens, PhD dissertation, Sussex European Institute, University of Sussex, Brighton.

Issawi, C.

1963 Egypt in Revolution: an Economic Analysis, Oxford University Press, London.

King, K.A.

2000 "Language ideologies and heritage language education", International Journal of Bilingual Education and Bilingualism, 3(3): 16784.

Kitromilides, P.

1983 "The Greek state as national centre", in D. Tsaousis (Ed.), Hellenism and Greekness: Ideological and Biographical Axes of Modern Greek Society, Estia, Athens: 143-64 (in Greek).

1990 "'Imagined communities' and the origins of the national question in the Balkans", in M. Blinkhorn and T. Veremis (Eds.), Modern Greece: Nationalism and Nationality, ELIAMEP, Athens: 23-64.

Lemmon, C.R., and J.P. Goggin

1989 "The measurement of bilingualism and its relationship to cognitive ability", Applied Psycholinguistics, 10: 133-55.

Li, Wei

1994 Three Generations, Two Languages, One Family, Multilingual Matters, Clevedon. 
Majid, A.M.J.

1991 Arabic Ethnic Groups in Greece. A Social Research, PhD dissertation, Department of Sociology, Panteion University, Athens (in Greek).

May, S.

2001 Language and Minority Rights, Longman, London.

2003 "Rearticulating the case for minority language rights", Current Issues in Language Planning, 4(2): 95-125.

McKinney, M.P.L., and T. Priestly

2004 "Telling tales out of school: assessing linguistic competence in minority language fieldwork", Journal of Multilingual and Multicultural Development, 25(1): 24-40.

Nikolinakos, M.

1973 "The contradictions of capitalist development in Greece: labour shortages and emigration", Studi Emigrazione, 30: 222-35.

Portes, A., and M. Zhou

1993 "The new second generation: segmented assimilation and its variants", Annals of the American Academy of Political and Social Science, 530: 74-98.

Rovolis, A., and A. Tragaki

2006 "Ethnic characteristics and geographical distribution of immigrants in Greece", European Urban and Regional Studies, 13(2): 99-111.

Rozakis, C.

1996 "The international protection of minorities in Greece", in K. Featherstone and K. Ifantis. (Eds.), Greece in a Changing Europe, Manchester University Press, Manchester: 95-116.

Sella-Mazi, E.

2001 Bilingualism and Society. The Greek Reality, Proskinio, Athens (in Greek).

Smolicz, J.J.

1992 "Minority languages as core values of ethnic cultures: a study of maintenance and erosion of Polish, Welsh, and Chinese languages in Australia", in W. Fase, K. Jaspaert and S. Kroon (Eds.), Maintenance and Loss of Minority Languages, John Benjamins, Amsterdam: 277-305.

Smolicz, J.J., and R.McD. Harris

1976 "Ethnic languages and immigrant youth", in M. Clyne (Ed.), Australia Talks: Essays on the Sociology of Australian Immigrant and Aboriginal Languages, Australian National University, Pacific Linguistics, Canberra: 131-175.

Smolicz, J.J., and M.J. Secombe

1985 "Community languages, core values and cultural maintenance" in M. Clyne (Ed.), Australia, Meeting Place of Languages, Pacific Linguistics, Australian National University, Canberra: 11-38. 
1989 "Types of language activation and evaluation in an ethnically plural society", in U. Ammon (Ed.), Status and Function of Languages and Language Varieties, Walter de Gruyter, Berlin: 478-514.

Smolicz, J.J., L. Lee, M. Murugaian and M.J. Secombe

1990 "Language as a core value of culture among tertiary students of Chinese and Indian origin in Australia", Journal of Asian Pacific Communication, 1(1): 229-46.

Smolicz, J.J., M.J. Secombe, and D.M. Hudson

2001 "Family collectivism and minority languages as core values of culture among ethnic groups in Australia”, Journal of Multilingual and Multicultural Development, 22(2): 152-72.

Smolicz, J.J., and R. Radzik

2004 "Belarusian as an endangered language: can the mother tongue of an independent state be made to die?' International Journal of Educational Development, 24: 511-28.

Spolsky, B.

2004 Language Policy, Cambridge University Press, Cambridge.

Stubbs, M. (Ed.)

1985 The Other Languages of England: Linguistic Minorities Project. Language, Education and Society, Routledge, London.

Tannenbaum, M.

2005 "Viewing family relations through a linguistic lens; symbolic aspects of language maintenance in immigrant families", Journal of Family Communication, 5(3): 229-52.

Thomson, M., and M. Crul

2007 "The second generation in Europe and the United States: how is the transatlantic debate relevant for further research on the European second generation?" Journal of Ethnic and Migration Studies, 33(7): 1025-41.

Triandafyllidou, A., and R. Gropas

2009 "Constructing difference: the Mosque debates in Greece", Journal of Ethnic and Migration Studies, 35(6): 957-75.

Triandafyllidou, A., and M. Maroufof

2008 "Immigration towards Greece at the Eve of the $21^{\text {st }}$ Century. A critical assessment" Report prepared for the IDEA project, ELIAMEP, Athens, May.

Trudgill, $\mathrm{P}$.

2002 Sociolinguistic Variation and Change, Edinburgh University Press, Edinburgh.

Tsitselikis, K.

2004 "The religious freedom of the immigrants: the case of the Muslims", in M. Pavlou and D. Christopoulos (Eds.), Greece of Migration, Kritiki, Athens: 267-302. 
Veremis, T.

1983 "State and nation in Greece: 1821-1912", in D. Tsaousis (Ed.), Hellenism and Greekness: Ideological and Biographical Axes of Modern Greek Society. Estia, Athens: 59-68 (in Greek).

1990 "From the national state to the stateless nation, 1821-1910", in M. Blinkhorn and T. Veremis (Eds.), Modern Greece: Nationalism and Nationality, ELIAMEP, Athens: 9-22.

Winnifrith, $\mathrm{T}$.

1992 The Vlachs. The History of a Balkan People, St. Martin's Press, New York. 